Information possibilities of the National bank of ukraine web-site in research of the history problems of monetary circullation in Ukraine 
УДК 94(477)

DOI: 10.31470/2518-7600-2019-8-320-335

INFORMATION POSSIBILITIES OF THE NATIONAL BANK OF UKRAINE WEB-SITE IN RESEARCH OF THE HISTORY PROBLEMS OF MONETARY CIRCULLATION IN UKRAINE

\title{
ІНФОРМАЦІЙНІ МОЖЛИВОСТІ САЙТУ НАЦОНАЛЬНОГО БАНКУ УКРАЇНИ В ДОСЛІДЖЕННІ ПРОБЛЕМ ІСТОРІЇ ГРОШОВОГО ОБІГУ В УКРАЇНI
}

\section{ИНФОРМАЦИОННЫЕ ВОЗМОЖНОСТИ САЙТА НАЦИОНАЛЬНОГО БАНКА УКРАИНЫ В} ИССЛЕДОВАНИИ ПРОБЛЕМ ИСТОРИИ ДЕНЕЖНОГО ОБРАЩЕНИЯ В УКРАИНЕ

\author{
Олексій Шевчук, \\ кандидат юридичних наук, \\ військовослужбовець \\ e-mail: \\ Alex2365480@gmail.com \\ ORCID: 0000-0002-2449-6894 \\ Researcher ID: AAE 5861-2019
}

Oleksiy Shevchuk, $\mathrm{PhD}$ in Law Sciences, Serviceman e-mail:

Alex2365480@gmail.com

ORCID: 0000-0002-2449-6894

Researcher ID: AAE 5861-2019

\section{ABSTRACT}

The article is devoted to the research of information opportunities of the National Bank of Ukraine's website in the history of monetary circulation study in Ukraine (1992-2019).

The development of science and technology in the modern world, especially the shuffling of information to digital technologies, requires researchers to make some changes in the research methods. Until a few decades ago, scientists referred to the main numismatic and bonistic sources - namely, individual banknotes (metal, ceramic and paper), fixation of places of monetary finds (coins, bonds), materials and instruments of monetary production, and also the weights in numismatics. Such 
sources as archival materials, legal sources, memoirs, epistolary heritage, and periodic publications have been traditionally referred to the secondary sources. However, the total informatization of the public administration and society has as the consequence that WEB resources become a significant source for historical research, including numismatic and bonistic ones. And exactly on these resources contains both primary and secondary sources of monetary history.

We have analyzed the correspondence of the National Bank of Ukraine website www.bank.gov.ua to the directions of public policy, which were proclaimed in 2019, among them: digitization, data openness and others. Thus, in the author's opinion, the site is quite user-friendly: it has a favicon (graphic logo), there was applied the same type of design for all the pages with mostly white and green tones and it has an English translation. The new version of the NBU site, which was developed in 2019, is more adequately displayed on smartphones and tablets. There is also a viewing version specifically for the visually impaired people. It has been proved that the NBU website has the considerable informational potential for researchers of the history of money circulation in Ukraine (1992-2019). The site presents the main source of numismatic and bonistic researches - the coins and banknotes of the National Bank of Ukraine; in particular, the site provides researchers with qualitative images of the main types and their description. Some interest for researchers, especially in the initial stages of scientific research, has another material, such as statistical information, explanations of the National Bank of Ukraine about cash circulation, banknote exchange, and others.

Keywords: National Bank of Ukraine, web site, information potential, monetary circulation, numismatics, bonistics, coins, banknotes.

Постановка проблеми. Розвиток науки i техніки у сучасному світі, особливо активне застосування цифрових технологій в інформаційній сфері, вимагає певних змін у використанні методів наукових досліджень. Український історик В.Орлик цілком слушно наголошує, що «інформаційні 
технології увійшли до наукового інструментарію істориків і стали невід'ємною частиною джерельної бази їхніх досліджень» (Орлик, 2013: 129). Дійсно, ще декілька десятиріч тому у нумізматичних та боністичних дослідженнях учені виділяли основні джерела - окремі грошові знаки (металеві, керамічні та паперові), знахідки грошових одиниць (монет, бон) (Орлик, 2017; Потильчак, 2018), матеріали та інструменти виготовлення грошових одиниць, а також вагові гирьки у нумізматиці (Потин, 1986: 71-72). Допоміжними джерелами у дослідженнях 3 проблем історії грошового обігу традиційно вважалися архівні матеріали (Орлик\&Маренець, 2005; Орлик\&Бойко-Гагарін, 2017), правові джерела (Орлик, 2019), мемуари та епістолярна спадщина, а також періодичні видання (Бойко-Гагарін, 2018). Проте внаслідок сучасної тотальної інформатизації державного управління та суспільства «комп'ютер, який має доступ до глобальної інформаційної мережі, перетворюється із засобу для редагування і друкування текстів на зручний інструмент для реалізації тонких джерелознавчих методик» (Жданович, 2010: 26). Власне й самі WEB-ресурси стають вагомим джерелом для історичних досліджень, зокрема й нумізматичних та боністичних.

Аналіз останніх досліджень і публікацій. Незважаючи на те, що WEB-ресурси $є$ досить новим видом джерел інформації, дослідження їхніх можливостей у вивченні питань історії грошового обігу знайшло певне відображення у історіографії. Це передусім публікації В. Орлика (Орлик, 2013) та його учнів О. Швець (Швець, 2015), О. Шпортун (Шпортун, 2016 a; 2016 b), В. Нечитайла (Нечитайло, 2019). Проблемам використання спеціального програмного забезпечення, яке значно розширює методологічний інструментарій дослідника, присвячена стаття І. Хромової (Хромова, 2015).

Метою статті $є$ вивчення інформаційних можливостей сайту Національного банку України (далі - НБУ) в дослідженні історії грошового обігу в Україні (1992-2019 рр.).

Виклад основного матеріалу. Дослідження ефективності функціонування державної установи в інноваційній економіці знаходиться в тісному взаємозв'язку з 
iї представленістю в мережі Інтернет, наявністю і якістю сайту, що є важливим аспектом системи електронного урядування. Саме тому одним із досить інформативних джерел дослідження історії грошового обігу в сучасній Україні і відповідно сучасної української нумізматики і боністики $є$ веб-сайт НБУ.

Проаналізуємо, наскільки веб-сайт НБУ https://www.bank.gov.ua/ відповідає проголошеним у 2019 році напрямкам державної політики, таким як цифровізація, відкритість даних та ін.

Відкриті дані на веб-сайті НБУ розподілені за наступними функціональними напрямками:

- монетарна політика;

- фінансова стабільність;

- нагляд;

- платежі та розрахунки;

- фінансові ринки;

- статистика;

- гривня.

Більша частина відкритих даних доступна не лише для перегляду, але і для експорту (як правило, в формат pdf, рідше в Xlsx).

Крім цього, головне меню сайту містить поле для користувацького пошуку, посилання на веб-сторінки 3 новинами (оновлюються кожного робочого дня) та інформацію про НБУ.

Сайт достатньо зручний для користування, має favicon (графічний логотип), однотипний дизайн усіх сторінок 3 переважно біло-зеленими тонами, переклад на англійську мову. Розроблена у 2019 році нова версія сайту НБУ більш адекватно відображається на смартфонах та планшетах. Також є версія перегляду, призначена для людей з вадами зору.

Статистика популярності веб-сайту, обсяги трафіку, географія аудиторії, ключові пошукові фрази можуть бути проаналізовані за допомогою інструментарію служби Google GoogleAnalytics (таблиця 1). 
Таблиия 1

\section{Показники значимості сайту НБУ https://www.bank.gov.ua за даними компаніï Google}

\begin{tabular}{|c|c|c|c|}
\hline Показник & \multicolumn{3}{|c|}{ Значення } \\
\hline IP адреса, сервер & \multicolumn{3}{|c|}{ 193.17.44.146, Україна } \\
\hline \multirow{2}{*}{ Перегляди } & День & Тиждень & Місяць \\
\hline & 118509 & 829565 & 3555278 \\
\hline \multirow{2}{*}{ Відвідувачі } & День & Тиждень & Місяць \\
\hline & 36766 & 257359 & 1102965 \\
\hline \multirow{2}{*}{ Структура посилань } & Внутрішні посилання & 221 & $90,57 \%$ \\
\hline & Зовнішні посилання & 23 & $9,43 \%$ \\
\hline Рейтинг у світі & \multicolumn{3}{|c|}{59308} \\
\hline Рейтинг в Україні & \multicolumn{3}{|c|}{564} \\
\hline $\begin{array}{l}\text { Географія аудиторії (за } \\
\text { останні } 30 \text { днів) }\end{array}$ & \multicolumn{3}{|c|}{ Україна - 53,6\% трафіку, Польща - 16,3\%, Нідерланди - 10,2\% } \\
\hline \multirow{6}{*}{ Ключові слова } & Фраза & Запитів в місяць & $\begin{array}{c}\text { Позиція сайту в } \\
\text { результатах пошуку }\end{array}$ \\
\hline & курс валют украина & 6600 & 18 \\
\hline & нбу курс валют & 3600 & 1 \\
\hline & курс на долара & 2900 & 14 \\
\hline & монети & 2900 & 4 \\
\hline & нбу & 2900 & 1 \\
\hline $\begin{array}{l}\text { Час, проведений на } \\
\text { кожній сторінці сайту і } \\
\text { в цілому на ньому }\end{array}$ & \multicolumn{3}{|c|}{$\begin{array}{c}\text { У цілому час, проведений на сайті - 00:02:50 } \\
\text { Переглядів сторінок на одного відвідувача - } 2,2\end{array}$} \\
\hline
\end{tabular}

Сайт НБУ має певні недоліки, здебільшого пов'язані 3 його недостатньою оптимізацією:

- занадто велике значення очікування відповіді від сервера (понад 4 с на мобільних пристроях), оптимальне значення має бути не більшим 200 мс;

- сайт не містить карти, що не дозволяє оцінити його змістове наповнення, глибину структури та взаємозв'язок сторінок;

- cайт не містить опису головної сторінки, а також жодного заголовка типу Н0-Н6, що знижує його рейтингові позиції за системою пошукової оптимізації SEO (англ. search engine optimization).

Але, незважаючи на певні недоліки, офіційний сайт НБУ має значний інформаційний потенціал для дослідження історії грошового обігу в Україні. Так, зокрема, на сайті міститься архів рішень 3 монетарної політики (Архів рішень з монетарної політики, 2019). Щоправда, облікові ставки зафіксовані 3 25.06.1992 р., а рішення НБУ щодо облікових ставок - 3 15.04.2014 р. Досить інформативними є статистичні матеріали 
сайту, зокрема, такі макроекономічні показники за 20182019 рр., як ціни (індекси споживчих цін, базовий індекс споживчих цін та індекси цін виробників промислової продукції) (Макроекономічні показники, 2019).

Проте найбільш цінною для дослідників сучасної української нумізматики i боністики є сторінка сайту, присвячена гривні (Гривня, 2019). Так, зокрема, на сторінці вказано, що НБУ є емісійним інститутом українських банкнот i монет, окрім цього зазначається, що банк контролює «банкноти протягом їхнього життєвого циклу, включаючи розроблення, виготовлення та обіг» (Гривня, 2019). Також на сторінці міститься літерний код української валюти (гривні) UAH, ï цифровий код - 980, скорочена назва - грн та графічний символ Ұ (Гривня, 2019).

Дана сторінка сайту НБУ розподілена за наступними функціональними напрямками:

- банкноти;

- монети;

- відео;

- історія української гривні;

- посилання;

- поширені питання;

- on-line замовлення пам'ятних монет України;

- пам'ятні та інвестиційні монети;

- новини.

Щодо інформаційного потенціалу зазначених напрямків аналізованої сторінки сайту НБУ, то необхідно зазначити, що усі вони мають окремі сторінки, які так само поділяються ще на декілька функціональних напрямків. Так, зокрема, на сторінці «Про банкноти» представлений увесь ряд обігових банкнот від 1 до 1000 грн (Про банкноти, 2019). Для дослідників історії українських паперових грошей (банкнот) дана сторінка є досить інформативною, адже містить не лише опис репрезентованих банкнот та зображення зразка, а й окрему сторінку з більш детальною інформацією відповідно до емісії. Так, наприклад, сторінка, присвячена банкноті номіналом 1 гривня, містить зображення зразків, описи лицьової та зворотної сторони, розмір, дату введення в обіг 
банкнот зразка 1992, 1994, 1995, 2004, 2005, 2006, 2011 та 2014 pp., а також опис елементів захисту цих банкнот (Банкнота номіналом 1 гривня, 2019). Аналогічна інформація щодо емісій банкнот інших номіналів міститься на відповідних сторінках.

Сторінка сайту «Про монети» містить загальну інформацію про те, що «розмінною монетою 3 найнижчим номіналом є 1 копійка», яка є сотою частиною «національної грошової одиниці України - гривні» (Про монети, 2019). Указується дата введення до обігу монет номіналом $1,2,5,10$, 25 і 50 копійок - 2 вересня 1996 р., а також те, що розмінні монети номіналом 1, 2 і 5 копійок були виведені з обігу 1 жовтня 2019 р. Щодо обігових монет номіналом 1 гривня зазначається, що вони були введені до обігу 12 березня 1997 р., a 27 квітня 2018 р. до грошового обігу було введено монети номіналом 1 гривня нового зразка та монети номіналом 2 гривні. Сайт інформує, що ці нові монети номінальною вартістю 1 і 2 гривні «перебуватимуть у обігу разом із монетами номіналом 1 гривня старого зразка й банкнотами номіналами 1 та 2 гривні попередніх років виготовлення» (Про монети, 2019).

Сторінка сайту «Про монети» розподілена за двома функціональними напрямками:

- монети в обігу;

- вийшли з обігу.

Функціональний напрямок «Монети в обігу» складається із опису монет, які 31 жовтня 2019 р. перебувають у грошовому обігу, а у групі «Вийшли з обігу» названо монети, які з 1 жовтня 2019 р. були вилучено з грошового обігу. Опис обох категорій монет містить фотографії монет кожного номіналу та інформацію про дати їхнього карбування, дату введення до обігу, найменування металу, з якого виготовлено монету, іiі метрологічні показники (діаметр, товщина та вага), прізвище художника (скульптора монет номіналом 1 і 2 гривні зразка 2018 р.). Більш детальний опис міститься на покликанні до кожної із представлених монет. Зокрема, указується, які номінали i в яких роках карбувалися на Луганському 
верстатобудівному заводі, які на Монетному дворі Італії, а які на Банкнотно-монетному дворі Національного банку України. Проте, на жаль, на сайті відсутні більш детальні матеріали 3 історії карбування монет на Луганському верстатобудівному заводі та на Монетному дворі Італії.

Досить цікавим є відеозапис презентацій на сторінці «Гривня», зокрема, презентації банкнот 500 та 1000 грн., а також презентації про оптимізацію банкнотно-монетного ряду.

Також на сторінці «Гривня», як зазначалося вище, розміщена рубрика «Поширені питання», відповіді на які містять відомості щодо регулювання готівкового обігу в Україні. Так, наприклад, досить інформативною є відповідь на питання про особливості «обміну зношених, пошкоджених, сумнівних щодо справжності та/або платіжності банкнот і монет» (Гривня, 2019). Зокрема, вказується, що «банки зобов'язані без будь-яких обмежень приймати для обміну від фізичних та юридичних осіб зношені банкноти, які не мають ознак підроблення та мають ознаки зношення або пошкодження: потертості, забруднення, відбитки штампів, надриви та надрізи, отвори, відірвані краї або кути. Касові працівники банківських установ повинні без обмежень приймати банкноти 3 ознаками значного зношення або пошкодження, які не мають ознак підроблення та які: зберегли цілу частину площею не менше ніж 55\% своєї початкової площі; розірвані (розрізані) на дві частини, на яких збереглись обидва однакові номери та серія, і загальна площа цих частин $\epsilon$ не меншою, ніж 55\% початкової площі банкноти. Пошкоджені банкноти, складені з двох або більше частин, банки зобов'язані вилучати з обігу і приймати на дослідження за ініціативою громадян-пред'явників як сумнівні щодо справжності та/або платіжності і в установленому порядку надсилати для проведення дослідження до відповідних територіальних підрозділів Національного банку. За результатами цих досліджень, які здійснюються Національним банком безкоштовно, клієнтам відшкодовується відповідна сума грошових знаків національної валюти, визнаних справжніми і платіжними. Якщо за результатами дослідження банкноти будуть визнані підробленими або пошкодженими під час 
надзвичайного режиму, їх буде вилучено 3 обігу без відшкодування їх вартості та в установленому порядку передано правоохоронним органам для проведення відповідного розслідування» (Гривня, 2019).

Висновки. Таким чином, сайт НБУ має значний інформаційний потенціал для дослідників історії грошового обігу в Україні (1992-2019 рр.). На сайті представлено основне джерело нумізматичних та боністичних досліджень - власне монети і банкноти НБУ, зокрема, якісні зображення основних типів та їхній опис. Певний інтерес для дослідників, особливо на початкових етапах наукових пошуків, має й інший матеріал, розміщений на даному ресурсі, наприклад, статистичні дані, роз'яснення НБУ щодо готівкового обігу, обміну банкнот та ін.

\section{ДЖЕРЕЛА ТА ЛІТЕРАТУРА}

1. Архів рішень 3 монетарної політики. URL: https://www.bank.gov.ua/monetary/stages/archive-rish (актуальність 25.10.2019).

2. Банкнота номіналом 1 гривня. URL: https://www.bank.gov.ua/uah/obig-banknote/1_2014 (актуальність 25.10.2019).

3. Бойко-Гагарін А.С. (2018). Газетна періодика як джерело вивчення процесів фальшування монет і банкнот у кінці XIX початку XX століття. Украӥнський нумізматичний щорічник. № 2. Переяслав-Хмельницький, 132-149. https:// doi.org/ 10.31470/ 2616-6275-2018-2-132-149

4. Гривня. URL: https://www.bank.gov.ua/uah (актуальність 25.10.2019).

5. Жданович О. В. Дослідницькі ресурси історичної тематики в мережі Інтернет: створення та використання: Дис. ... канд. іст. наук: 07.00.06 / НАН України, Ін-т історії України. К., 2010. 210 c

6. Макроекономічні показники. URL: https:// www.bank.gov. ua/ statistic/macro-indicators (актуальність 25.10.2019).

7. Нечитайло, В.В. (2019). Інформаційний потенціал Інтернет-ресурсів у вивченні проблем грошового обігу України-Гетьманщини. Соціум. Документ. Комунікація: збірник наукових статей. Серія «Історичні науки», 7, 77-87. 
8. Орлик, В. (2017). Топографія знахідок в Україні монет держави Тевтонського ордену в Пруссії та ii Лівонського відділення (зведені відомості по областях). Український нумізматичний щзорічник, 1, 37-74.

9. Орлик, B.M. (2013). Інформаційний потенціал WEBресурсів у нумізматичних дослідженнях (на прикладі монет держав Хрестоносців). Матеріали наукової конферениії 3 міжнародною участю «Архівознавчі та джерелознавчі галузі знань: проблеми взаємодї̈ на сучасному етапі». 14 березня 2013 р., К., 129-133.

10. Орлик, В. \& Маренець, Л. (2005). До питання фіскальної політики нацистів в окупованій Україні. Архіви Украӥни, 1-3, 233-240. URL: http://nbuv. gov. ua/UJRN/ay_2005_1-3 (256)_25.

11. Орлик, C. \& Бойко-Гагарін, A. (2017). Фальшивомонетництво в Україні в роки Першої світової війни. Український нумізматичний щзорічник, 1, 143-164.

12. Орлик, С. (2019). Правові джерела з історії податкової політики уряду Російської імперії в роки Першої світової війни. Соціум. Документ. Комунікація, 7, 160-182.

13. Потильчак, О. (2018). Мідна російська монета у грошовому обігу Правобережної України у XVIII ст. (на матеріалах нумізматичних знахідок 2017 року з Трушків на Білоцерківщині). Украӥнський нумізматичний щзорічник, 2, 119131. URL: https://doi.org/10.31470/2616-6275-2018-2-119-131

14. Потин, В.М. (1986). Введение в нумизматику. Tруды Государственного ордена Ленина Эрмитажа. Ленинград: Искусство, T.XXVI. Ч. 6. С. 69-162.

15. Про банкноти. URL: https://www.bank.gov.ua/uah/obigbanknote (актуальність 25.10.2019).

16. Про монети. URL: https://www.bank.gov.ua/uah/obig-coin (актуальність 01.11.2019).

17. Хромова, І.К. (2015). Програмне забезпечення у нумізматичному дослідженні колекції. Спеціальні історичні дисцииліни: питання теорії та методики. Електронні інформачійні ресурси. Збірка наукових працьь, 25, 173-179.

18. Швець, О. (2015). Використання інформаційних ресурсів у нумізматичних дослідженнях. Тези доповідей III Міжнародної науково-практичної конференцї «Актуальні 
проблеми нумізматики в системі допоміжних історичних дисциилін». 5-6 листопада 2015 р. Кіровоград-Київ-ПереяславХмельницький, 15-18.

19. Шпортун, О. (2016 а). Нумізматичні веб-сайти України. Studia I Materialy «Forum Numizmatyczne, Pieniadz I Mennice», 1, 174-179.

20. Шпортун, О. (2016 b). Проблеми використання сайту «Auction.violity.com» в нумізматичних дослідженнях. Збірник працьь IV Міжнародної науково-практичної конферениіі «Актуальні проблеми нумізматики в системі допоміжних історичних дисциплін». 22-23 червня 2016 р. Кіровоград-КиївПереяслав-Хмельницький, 125-127.

\section{REFERENCES}

1. Arkhiv rishen z monetarnoi polityky [Archive of monetary policy decisions]. URL: https://www.bank.gov.ua/ monetary/ stages/archive-rish (aktualnist 25.10.2019) [in Ukrainian].

2. Banknota nominalom 1 hryvnia [Banknote of 1 hryvnia]. URL: https:// www.bank.gov.ua/ uah/ obig-banknote/1_2014 (aktualnist 25.10.2019) [in Ukrainian].

3. Boiko-Haharin, A.S. (2018). Hazetna periodyka yak dzherelo vyvchennia protsesiv falshuvannia monet $\mathrm{i}$ banknot $\mathrm{u}$ kintsi $\mathrm{KhIKh}$ - pochatku KhKh stolittia [Newspaper Periodicals as a Source for Studying the Counterfeiting of Coins and Banknotes in the Late Nineteenth - Early Twentieth Centuries]. Ukrainskyi numizmatychnyi shchorichnyk, 2, 132-149. URL: https://doi.org/ 10.31470/2616-6275-2018-2-132-149 [in Ukrainian].

4. Hryvnia [Hryvnia]. URL: https://www.bank.gov.ua/uah (aktualnist 25.10.2019) [in Ukrainian].

5. Zhdanovych, O. V. (2010). Doslidnytski resursy istorychnoi tematyky v merezhi Internet: stvorennia ta vykorystannia: Dys. ... kand. ist. nauk: 07.00.06 [Historical-themed research resources on the Internet: creation and use: Dis. ... Cand. ist. Sciences: 07.00.06]/ O.V. Zhdanovych ; NAN Ukrainy, In-t istorii Ukrainy. K., 210 [in Ukrainian].

6. Makroekonomichni pokaznyky [Macroeconomic indicators]. URL: https:// www.bank.gov.ua/ statistic/ macro-indicators (aktualnist 25.10.2019) [in Ukrainian]. 
7. Nechytailo, V.V. (2019). Informatsiinyi potentsial Internetresursiv u vyvchenni problem hroshovoho obihu Ukrainy-Hetmanshchyny [Information potential of Internet resources in the study of problems of monetary circulation of Ukraine-Hetmanate.]. Sotsium. Dokument. Komunikatsiia: zbirnyk naukovykh statei. Seriia «Istorychni nauky», 7, 77-87 [in Ukrainian].

8. Orlyk, V. (2017). Topohrafiia znakhidok v Ukraini monet derzhavy Tevtonskoho ordenu $\mathrm{v}$ Prussii ta yii Livonskoho viddilennia (zvedeni vidomosti po oblastiakh) [Topography of finds in Ukraine of Teutonic Order coins in Prussia and its Livonian Branch (summary information by region)]. Ukrainskyi numizmatychnyi shchorichnyk, 1, 37-74 [in Ukrainian].

9. Orlyk, V.M. (2013). Informatsiinyi potentsial WEB-resursiv u numizmatychnykh doslidzhenniakh (na prykladi monet derzhav Khrestonostsiv) [Information potential of WEB-resources in numismatic studies (on the example of Crusader states).]. Materialy naukovoi konferentsii z mizhnarodnoiu uchastiu "Arkhivoznavchi ta dzhereloznavchi haluzi znan: problemy vzaiemodii na suchasnomu etapi». 14 bereznia 2013 r., Kyiv, 129-133 [in Ukrainian].

10. Orlyk, V. \& Marenets, L. (2005). Do pytannia fiskalnoi polityky natsystiv $v$ okupovanii Ukraini [The question of the fiscal policy of the Nazis in occupied Ukraine]. Arkhivy Ukrainy, 1-3, 233-240. URL: http://nbuv. gov. ua/UJRN/ay_2005_1-3 (256)__25 [in Ukrainian].

11. Orlyk, S. \& Boiko-Haharin, A. (2017). Falshyvomonetnytstvo v Ukraini v roky Pershoi svitovoi viiny [Counterfeiting in Ukraine during the First World War]. Ukrainskyi numizmatychnyi shchorichnyk, 1, 143-164 [in Ukrainian].

12. Orlyk, S. (2019). Pravovi dzherela $\mathrm{z}$ istorii podatkovoi polityky uriadu Rosiiskoi imperii v roky Pershoi svitovoi viiny [Legal sources on the history of tax policy of the Government of the Russian Empire during the First World War ]. Sotsium. Dokument. Komunikatsiia, 7, 160-182 [in Ukrainian].

13. Potylchak, O. (2018). Midna rosiiska moneta u hroshovomu obihu Pravoberezhnoi Ukrainy u XVIII st. (na materialakh numizmatychnykh znakhidok 2017 roku z Trushkiv na 
Bilotserkivshchyni) [Copper Russian Coin in the Circulation of Right-Bank Ukraine in the 18th Century (based on numismatic findings 2017 from Trushkiv in Belotserkovschyna)]. Ukrainskyi numizmatychnyi shchorichnyk, 2, 119-131. URL: https://doi.org/10.31470/2616-6275-2018-2-119-131 [in Ukrainian].

14. Potyn, V.M. (1986). Vvedenye v numyzmatyku [Introduction to numismatics]. Trudbl Hosudarstvennoho ordena Lenyna Эrmytazha. Lenynhrad: Yskusstvo, T.KhKhVI, 6, 69-162 [ in Russian].

15. Pro banknoty [About banknotes]. URL: https:// www.bank.gov.ua/uah/ obig-banknote (aktualnist 25.10.2019) [in Ukrainian].

16. Pro monety [About coins]. URL: https:// www.bank.gov.ua/ uah/obig-coin (aktualnist 01.11.2019) [in Ukrainian].

17. Khromova, I.K. (2015). Prohramne zabezpechennia u numizmatychnomu doslidzhenni kolektsii [Software in numismatic collection research]. Spetsialni istorychni dystsypliny: pytannia teorii ta metodyky. Elektronni informatsiini resursy. Zbirka naukovykh prats, 25, 173-179 [in Ukrainian].

18. Shvets, O. (2015). Vykorystannia informatsiinykh resursiv u numizmatychnykh doslidzhenniakh [Use of information resources in numismatic studies]. Tezy dopovidei III Mizhnarodnoi naukovopraktychnoi konferentsii «Aktualni problemy numizmatyky $v$ systemi dopomizhnykh istorychnykh dystsyplin». 5-6 lystopada $2015 \mathrm{r}$. Kirovohrad-Kyiv-Pereiaslav-Khmelnytskyi, 15-18 [in Ukrainian].

19. Shportun, O. (2016 a). Numizmatychni veb-saity Ukrainy [Numismatic websites of Ukraine]. Studia I Materialy «Forum Numizmatyczne, Pieniadz I Mennice». 1, 174-179 [in Ukrainian].

20. Shportun, O. (2016 b). Problemy vykorystannia saitu «Auction.violity.com» V numizmatychnykh doslidzhenniakh [Problems of using Auction.violity.com in numismatic research]. Zbirnyk prats IV Mizhnarodnoi naukovo-praktychnoi konferentsii "Aktualni problemy numizmatyky $v$ systemi dopomizhnykh istorychnykh dystsyplin». 22-23 chervnia 2016 r. Kirovohrad-KyivPereiaslav-Khmelnytskyi, 125-127 [in Ukrainian].

\section{АНОТАЦІЯ}

Стаття

присвячена аналізу інформаційних можливостей сайту Національного банку Украӥни для вивчення історії грошового обігу в Украӥні (1992-2019 рр.). 
Розвиток науки і техніки в сучасному світі, особливо активне застосування ичирових технологій в інформаційній сфрері, вимагають певних змін у використанні методів наукових досліджень. Ще декілька десятиріч тому до основних нумізматичних та боністичних джерел учені відносили власне окремі грошові знаки, фіксачію місць знахідок грошових одиниць (монет, бон), матеріали та інструменти виготовлення грошових одиниць, а також вагові гирьки в нумізматиці. До допоміжних традиційно зараховували архівні матеріали, правові джерела, мемуари, епістолярну спадшину та періодичні видання. Проте тотальна інформатизація державного управління та суспільства призвели до того, щзо WEB-ресурси стають вагомим джерелом для історичних досліджень, зокрема й нумізматичних та боністичних. Саме на ичих ресурсах містяться як основні, так $i$ допоміжні джерела з історії грошового обігу.

Проаналізовано відповідність веб сайту НБУ https://www.bank.gov.ua/ проголошеним у 2019 році напрямкам державної політики, таким як циифровізація, відкритість даних та ін. На думку автора, сайт достатньо зручний для користування, має favicon (графічний логотип), однотипний дизайн усіх сторінок з переважно біло-зеленими тонами, переклад на англійську мову. Розроблена у 2019 роичі нова версія сайту НБУ відображається на смартфонах та планшетах. Також є версія перегляду, призначена для людей з вадами зору.

Доведено, щзо сайт НБУ має значний інформаизійний потенціал для дослідження історії грошового обігу в Украӥні (1992-2019 рр.). На сайті представлено основне джерело нумізматичних та боністичних досліджень - власне монети $i$ банкноти НБУ, якісні зображення їх основних типів та опис. Певний інтерес для дослідників, особливо на початкових етапах наукових пошуків, мають статистичні дані, роз 'яснення НБУ щуодо готівкового обігу, обміну банкнот та $i$.

Ключові слова: Національний банк Украӥни, веб сайт, інформаційний потенціал, грошовий обіг, нумізматика, боністика, монети, банкноти. 


\section{АННОТАЦИЯ}

Статья посвящена анализу информационных возможностей сайта Национального банка Украинь для изучения истории денежного обращуения в Украине (1992-2019 22.).

Развитие науки и техники в современном мире, особенно активное применение цифровых технологий в информационной сфере, требует определенных изменений в использовании методов научных исследований. Ещуе несколько десятилетий назад к основным нумизматическим и бонистичных источникам ученые относили - собственно отдельные денежные знаки, фиксацию мест находок денежных единиц (монет, бон), материаль и инструменты изготовления денежных единиц, а также весовые гирьки в нумизматике. К вспомогательным традиционно относили архивные материаль, правовые источники, мемуары, эпистолярное наследие и периодическую печать. Однако тотальная информатизация государственного управления и общества привели к тому, что WEB-ресурсы становятся важным источником для исторических исследований, в том числе нумизматических и бонистичних. Именно на этих ресурсах содержатся как основные, так и вспомогательные источники по истории денежного обрашуения.

Проанализировано соответствие сайта НБУ https://www.bank.gov.ual провозглашеннылм в 2019 году направлениям государственной политики, таким как цүифровизачия, открытость данных и др. По мнению автора, сайт достаточно удобный для пользования, имеет favicon (графический логотип), перевод на английский язык, однотипный дизайн всех страниц с преимущзественно белозелеными тонами. Разработанная в 2019 году новая версия сайта НБУ отображается на смартфонах и планшетах. Также есть версия просмотра спещиально для слабовидящих.

Доказано, что сайт НБУ имеет значительный информационный потенцииал для исследователей истории денежного обращуения в Украине (1992-2019 г2.). На сайте представлено основной источник нумизматических и бонистичных исследований - собственно монеты и банкноты 
НБУ, в частности, качественные изображения их основных типов и описание. Определенный интерес для исследователей, особенно на начальных этапах научных изысканий, имеют статистические данные, разъяснения НБУ относительно наличного обращения, обмена банкнот и др.

Ключевые слова: Нацииональный банк Украины, веб сайт, информационный потенциал, денежное обращчение, нумизматика, бонистика, монеть, банкнотьл. 